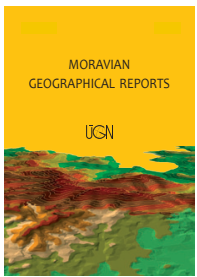

MORAVIAN GEOGRAPHICAL REPORTS

\title{
Some dilemmas of post-industrialism in a region of traditional industry: The case of the Katowice conurbation, Poland
}

\author{
Robert KRZYSZTOFIK $^{\text {a* }}$, Maria TKOCZ a , Tomasz SPÓRNA a , Iwona KANTOR-PIETRAGA ${ }^{\text {a }}$
}

\begin{abstract}
The problem of using the concept of post-industrialism to define regions with traditional industries is addressed in this article. It focuses on the diversity of industrial development in the Katowice conurbation (Poland) and the difficulties of situating the region in the widely-used taxonomy by Phelps and Ozawa, which assumes a one-way transition from the late-industrial to post-industrial stage. The authors point to the fact that only some of the towns can be described as post-industrial, since there are also towns in which traditional industries continue to develop relatively well and others at an advanced stage of re-industrialisation. The proposal is made that the Katowice conurbation can be described as a "trans-industrial region" in order to account for the various stages of development in the industrial sector in the towns of the conurbation, and to underline the dynamic nature and temporal variability of the industrialisation factor in the region.
\end{abstract}

Keywords: post-industrial region, re-industrialisation, de-industrialisation, the Katowice conurbation, Poland

Article history: Submitted 25 March 2015; Accepted 25 January 2016; Published 31 March 2016

\section{Introduction}

In Europe, many significant large urban regions have their origins from nineteenth and twentieth century developments of industry and mining. The largest European urban conurbations of this kind are the Ruhr region in Germany, Nord/Pas-de-Calais on the border of France and Belgium, the Ostrava region in the Czech Republic, Donbass in Ukraine, or the Upper Silesian Coal Basin and the Dabrowa Basin in Poland. In most cases, these are polycentric regions, defined as urban conurbations here. The functioning of such regions, determined by industrial and mining sectors, makes them economically and spatially specific. Another characteristic feature of such regions is that the dynamics of transformations are defined not only with regard to path dependence, but also with the variability and evolution of the process of industrialisation itself.

Both spatial and temporal attributes of conurbations significantly differ from those characteristic of monocentric urban agglomerations whose development was based on mixed functions: service, trade and production, frequently strengthened by administrative functions, in particular, capital cities. London, Paris and Moscow, as well as Prague, Warsaw, and Stockholm, provide good examples of such agglomerations.
Another type of urban region is the polycentric agglomeration, whose development is an effect of their geographical proximity to even larger cities (Parr, 2004; Meijers, 2008). Such systems have a complex functional genesis, and the nature of the development of the towns that form them is determined by production, as well as by services and administrative functions. Randstad Holland or the Saxony triangle in Germany (Kloosterman and Lambregts, 2001; Hudec and Urbančiková, 2008; Franz, 2010) can be mentioned here.

The genesis of urban agglomerations, however, is only the initial phase of their existence. The functional identity of a given agglomeration converges with later stages of development only when the functional component which brought them into existence is relatively permanent. This is particularly visible in the large industrial-mining conurbations.

Functional transformations are also evident today. They follow at least two opposing directions and are conditioned by either centrifugal or centripetal forces (Krugman, 1997; Krzysztofik, 2014). Changes in the functional character of European agglomerations have been visible since at least since the mid-twentieth century. On the one hand, there has been a strengthening of the potential of the

\footnotetext{
${ }^{a}$ Department of Economic Geography, Silesian University, Sosnowiec, Poland (*corresponding author: R. Krzysztofik, e-mail: robert_krzysztofik@interia.pl)
} 
monocentric agglomerations and those polycentric ones whose development was the effect of the convergence of urban areas of larger towns. On the other hand, there is a decomposition of the functional basis of those urban regions whose development depended on a strong industrial function, in particular mining (Domański, 2003; Birch et al., 2010; Neffke et al., 2011). In the research literature, explanations of the functional changes in regions with mining and industrial genesis have been correctly based on processes of de-industrialisation, including closures of industries and their re-structuring. This aspect has been emphasized in numerous explanatory studies and multi-regional studies (Scott, 1982; Hamilton, 1984; Scott and Storper, 1987; Lever, 1991; Strangleman, 2002; Steiner, 2003; Müller et al., 2004; Lux, 2009; Musil, 2010; Coenen et al., 2014).

An equally important role in explaining these transformations has been played by analyses of specific regions traditionally perceived as industrial or post- industrial, such as Ruhrgebiet (Knapp, 1998; Van Dijk, 2002; Eckart, 2003), the Ostrava region (Sucháček, 2005, 2010; Hruška-Tvrdý, 2010; Rumpel nad Slach, 2012), Donbas (Swain, 2007), Nord/Pas-de-Calais (Leboutte, 2009), the Katowice conurbation (Klasik and Heffner, 2001; Tkocz, 2001, 2003; Domański, 2002; Mikołajec, 2008) and others (Cooke, 1995; Hassink and Shin, 2005; Trippl and Otto, 2009; Wirth et al., 2012). Although research results and conclusions in some of these works are diverse, as a whole they form the bases for a critical analysis of the issues under discussion here. Hence, the critical analysis of some case studies and existing theoretical explanations constitute further generalisations made in this contribution.

With reference to the functional changes taking place in the Katowice region (see Fig. 1), which is analysed in this article, an attempt is made to define the region's character using the taxonomy suggested by Phelps and Ozawa (2003), as pre-industrial, late-industrial and post-industrial stages.

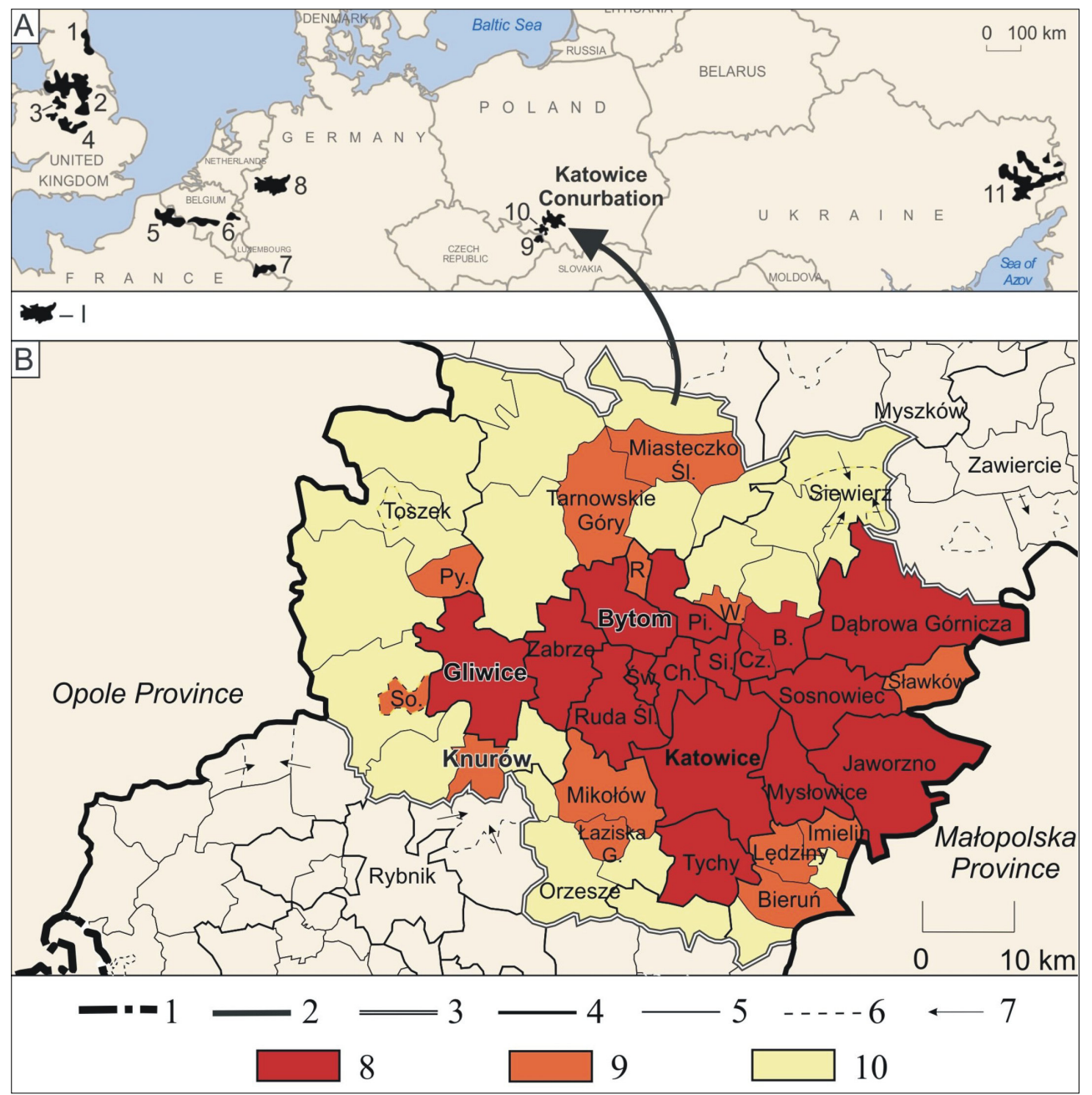

Fig. 1: The Katowice conurbation - location and administrative divisions

Notes: Fig. 1A: 1 -Tyneside Conurbation; 2-West Yorkshire Urban Area and Greater Manchester Urban Area; 3 - North Staffordshire Conurbation; 4 - West Midlands Conurbation (The Black Country); 5 - Nord-Pas-De-Calais (Nord-Pas-de-Calais Coal Basin); 6-Mons-Charleroi Region (The Pays Noir, Black Country) and Ličge (Ličge Coal Basin); 7 - Saar/ Saargebiet (Saar-Warndt Coal Basin); 8 - Ruhr/ Ruhrgebiet (Ruhr Coal Basin); 9 - The OstravaKarvina Agglomeration (Upper Silesian Coal Basin); 10 - The Rybnik Conurbation (Upper Silesian Coal Basin); 11 - Donbas (Donetsk Coal Basin). Fig. 1B: 1 - boundary of Poland, 2 - province boundaries, 3 - Katowice conurbation boundaries, 4 - poviat (NUTS 4), 5 - gmina (NUTS 5), 6-boundaries between city in urban-rural gmina and rural area, 7 - rural area in urban-rural gmina, 8 - core of conurbation, 9 - inner zone of conurbation, 10 - outer zone of conurbation. Normal text-city, B. - Będzin, Ch. - Chorzów, Cz. - Czeladż, Pi-Piekary Ślaskie, Py-Pyskowice, R. Radzionków, Si. - Siemianowice Ślaskie, So. - Sośnicowice, Św. - Świętochłowice, W. - Wojkowice. Bytom, Gliwice, Knurów are the case studies used in this paper.

Sources: Author's elaboration. 
The use of this categorisation is dictated by the fact that it includes both dynamic and functional aspects of possible explanations. Another advantage is that, to a large extent, it concerns regions forming urban conurbations based on mining and industrial sectors.

The relations between industrialisation, deindustrialisation and re-industrialisation are subject to review initially. It has been assumed that these processes provide key contexts for defining the region as one at the late-industrial and post-industrial stages. Considering the issue of re-industrialisation, broadly understood as a renewed development of industrial functions, however, there appears to be a certain conceptual dissonance. Therefore, the basic aim of this article is to question whether the process of reindustrialisation undermines the validity of describing the region as late-industrial or, perhaps even more so, as postindustrial. Is there another stage of the transformations? If so, what is its nature? Some new proposals are formulated in response to these questions on the specific nature of functional transformations in regions whose genesis was based on industrial and mining functions.

\section{Theoretical background}

\subsection{Mechanisms of development}

The research problems discussed here are situated at the interstices between urban and economic geography and the new economic geography. On the one hand, the paper interprets the evolution of an urban conurbation; on the other, it stresses the role of economic factors in its continuity and structure. This seemingly well-known system of dependencies demands, however, further research, as has been recently pointed out by Gwosdz and Sobala-Gwosdz (2012).

The necessity of a more general background against which urban forms and functions should be considered is a first consideration. In this respect, a useful approach is the one assuming the basic role of centripetal and centrifugal forces in shaping the socio-economic and spatial system of regions (Krugman, 1997). Each of the above-mentioned forces, which are also city-forming forces, can predominate in a given area and place. They can also, particularly at present, balance each other. Assuming that the Katowice conurbation discussed in this article has been created by centrifugal city-forming forces (Gwosdz and Sobala-Gwosdz, 2012; Krzysztofik, 2014), their contemporary weakness, and in some places disappearance, constitutes a key framework for explaining the spatial imbalance of the industrial potential of the region. But the weakness and disappearance of the socioeconomic attributes defining each of the city-forming forces do not always mean that the gap will be filled by attributes represented by the opposing type of city-forming forces. In practice, frequently the former traditional attribute, for example an obsolete industrial plant, is replaced by a new attribute - a modern industrial plant from another sector of industry. Functionally, they both represent the consequences of the influence of the same city-forming forces, in this case centrifugal ones.

The centrifugal city-forming forces in the Katowice region were visible in the mass exploitation and production of material goods exported beyond the local resources, which led to several important effects:
- the emergence of a network of city-forming points near industrial and mining facilities;

- an intra-urban, strongly specialized economic base, generally independent from supply and demand in the rural or less-urbanized surrounding region (as in central place theory formulations, for example). Bituminous coal or goods produced by the processing industry were exported to any place in Europe or the world, depending on the demands of supra-local markets. A part of coal or steel production was used in situ as an element of a longer cycle of manufacturing, whose products finally were exported outside the region. Relations between the town and other regions (as markets) outside the region dominated those between the town and the surrounding region (with the exception of the above-mentioned endogenous connections in industry); and

- the creation of a system of centrifugal city-forming forces determined by centrifugal systems of the economic bases of the towns in the conurbation.

If the impact and interactions of city-forming forces in a region are determined in every region predominantly by the size and structure of the economic potential (Krugman, 1997), it can be assumed that in heavily industrialized and mining regions this attribute is definitely the determining one. Today, however, the economic development of regions with traditional industries in Central-Eastern Europe tends to be influenced by three processses: (1) the continued functioning of industrial plants constructed in the industrial and lateindustrial stages, which is occurring mainly in the mining industry and large industrial plants from other sectors with more than 1000 employees; (2) re-industrialisation based on new industrial plants, frequently based on investments representing sectors that are new to the regions, and they are often situated in special economic areas or functionally derelict areas, including brownfields; and (3) investments in the service sector, particularly large area investments (trade, logistics) and to a lesser extent in R\&D sector investments (Gwosdz, 2014; Klasik, 2008; Popjaková et al., 2014).

\subsection{The question of post-industrialism with a special focus on Phelps and Ozawa's concept}

This listing of business ventures determining the development of formerly strictly mining or mining-industrial regions in Central-Eastern Europe, stresses three of the theoretical issues defined by Phelps and Ozawa (2003).

Firstly, these regions are in the final stages of their late-industrial or post-industrial evolution or relatively somewhere in between these stages. Phelps and Ozawa (2003) correctly phase this evolution, pointing out some classical directions of changes in the functional database already existing in geographical space, which generally can be determined by the phrase: from industry to services. Also, in most cities in the Katowice region examined in this article, the service function dominated the industrial function.

Secondly, an essential feature of the post-industrialism of old industrial districts should be pointed out, which Phelps and Ozawa (2003, p. 593-594) believe to be the borrowed size of towns ${ }^{1}$. As shown in further explanation below, this element of the evolution of changes in the post-industrial region is again characteristic for the analysed conurbation.

\footnotetext{
${ }^{1}$ The meaning of this term, which was proposed by Alonso in the 1970s, has recently been extended to include cities located outside the old industrial and mining districts (Burger et al., 2015).
} 
The third issue related to the Katowice conurbation, as in many other cases, is the fact that post-industrialism, understood as a functional change, is accompanied by two more phenomena: re-industrialisation and urban shrinkage combined with de-industrialisation. The effect of the former is a restriction on the increasing role of services in relation to industrial functions (see Gwosdz, 2014). The effect of the latter is an overall decrease of the region's economic potential, accompanied by de-urbanisation and de-industrialisation (Krzysztofik et al., 2014).

Those regions in Central-Eastern Europe that are traditionally described as post-industrial have been shown to undergo the following changes:

a. change in functional structure due to the increasing role of services at the cost of the industrial functions (postindustrialism);

b. some continuation of still significant potential of mining and traditional industry (late-industrialism);

c. attempts at re-introducing industrial functions, often unrelated to the structure of industry sectors (reindustrialism); and

d. the disappearance of all exogenous ${ }^{2}$ functions (exogenous services, industry, mining) with a simultaneous exposure of endogenous functions (complete de-industrialisation, de-urbanisation and urban shrinkage).

Taking into account the above-listed changes, one should ask whether the regions should be treated as "postindustrial' in the literal sense of the word. The dissonance is particularly noted in the interaction between temporallyand spatially-identical post-industrialism (point a), lateindustrialism (point b) and re-industrialism (point c), with Sosnowiec providing one of the more interesting examples in the Katowice conurbation (Krzysztofik et al., 2013).

\subsection{The question of re-industrialisation}

A separate issue in considering re-industrialisation in the context of post-industrialism is the question about the future development paths of large industrial regions. Generally, one can notice that a gradual disappearance of traditional industries is constantly balanced by industrial investments based on new and medium-advanced technologies (Borowik, 2014; Westkämper, 2014). An important role here is performed by the search for a new spatial policy ${ }^{3}$ for the development of industry, as well as by the placement of the policy of re-industrialisation in the canon of EU economic development.

A slightly different economic-spatial policy with regard to re-industrialisation can be observed in Russia, for example, where, alongside the need to create new industries, particular attention is paid to the strong need for technological and organisational modernisation of traditional industrial centres, in particular of the electrical and machine industries (Schuysky, 2013; Dubenetskii, 2014).

At this point, however, the issue of the re-industrialisation model should be addressed. The essential question in this context is whether the development of new businesses in the Katowice region meets the criteria for one of the four developments of the concept of New Industrial Districts (NID) proposed by Markusen (1996), or does it rather adopt an individual model of development? Markusen (1996, p. 296) distinguished four forms of industrial districts: The Marshallian NIDs, including the Italian form; "the huband-spoke" districts; the satellite industrial platforms; and the state-centred districts. The division was later extended and improved by Pickernell et al. (2007) and Cornell (2013). Referring to this typology, the initial thesis may be that the development of re-industrialisation in the Katowice region is closest to "the hub-and-spoke" model. This model for the Katowice conurbation, however, has its own characteristic features, as discussed below.

\section{De-industrialisation and re-industrialisation of the region after 1989}

The emergence of a highly urbanised conurbation in the south of Poland was connected with bituminous coal mining and the steel industry (Riley and Tkocz, 1999). By the end of the nineteenth century, the core of the contemporary urban region was formed, and by the middle of the twentieth century town charters were given to all towns in the region. The urbanisation of the region included the spatial development of settlements near or next to the largest coal mines, steelworks, and industrial plants. Since the mid-twentieth century, this network of often loosely connected settlements began to integrate into a system of large (over 100 thousand inhabitants) and medium-size towns. The last stage of integration took place in the 1970s (Gwosdz, 2014; Krzysztofik, 2014).

\subsection{De-industrialisation}

The first symptoms of an economic crisis in the region's industries were noticed already in the 1980s, but it was only in the 1990s that a number of radical changes took place (Fig. 2). Except for the automotive and power engineering industries, these changes consisted in closing down and restructuring industrial plants. All sectors underwent commercialisation and privatisation. The automotive industry and power engineering did relatively well - all of the larger plants in these sectors were modernized and expanded - but the overwhelming majority of local traditional industries suffered dramatically. Most bituminous coal mines were closed down or merged, and the steel industry was thoroughly restructured: steelworks with 2-4 thousand workers were turned into metallurgical plants with less than 1,000 employees, and some (Gliwice) were closed down. In 1980, there were over 20 thousand people employed in Huta Katowice (Arcelor Mittal) in Dąbrowa Górnicza; after 2010, there were only some 5,000, including those employed in companies working for the steelworks. Light industry disappeared almost completely: out of six big production plants, four were closed down and the other two were thoroughly restructured. Similarly, nonferrous metals industries, coking, chemical and mineral industries underwent restructuring. A significant number of plants in the metal, machine, and electro-technical sectors went bankrupt, including those constructed in the 1970s.

The de-industrialisation of the region is a continuous process which was particularly intense in the period between 1994 and 2004. At that time, all features of deindustrialisation were visible: the highest number of large

\footnotetext{
2 The terms "exogenous functions" and "endogenous functions" are used in the context of traditional economic base analysis.

${ }^{3}$ There should be a public discussion about expected types of industry in Gliwice and Katowice and also a question of future development of some investment areas - whether they should develop towards industry or services?
} 


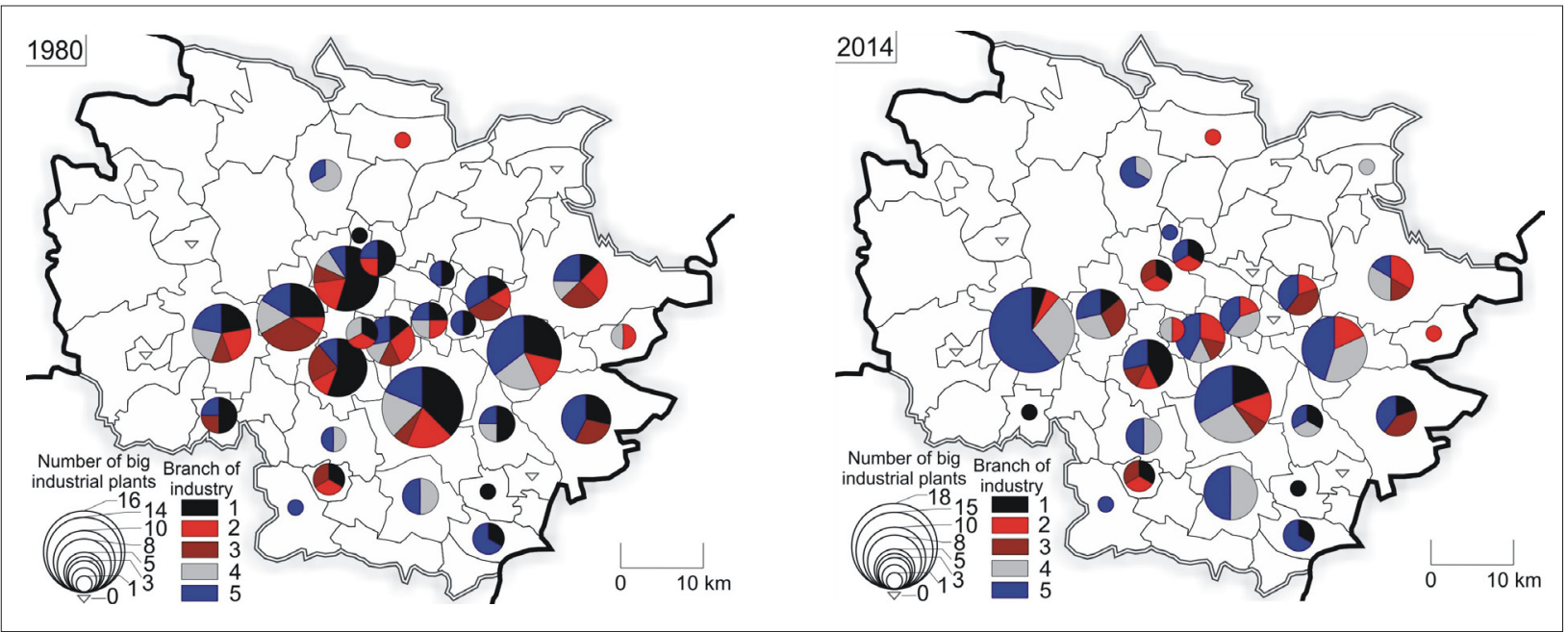

Fig. 2: Number and structure of industrial plants in the Katowice conurbation in 1980 and 2014 (Legend: 1 -coalmining; 2 - steelworks and non-ferrous sector; 3 - power stations and coke plants; 4 - metal-, machinery-and electrotechnical industry plants; 5 - industrial plants representing other branches)

Source: authors

and medium-size companies was closed down; the highest number of employees were fired or sent on holidays; the greatest decline in manufacturing sales; and the largest decreases in profitability were noticed. In this period, the number of jobs in industries was reduced by as much as 400 thousand in the region. According to Tkocz (2003, p. 38), about 280,000 people left the coal mining sector in southern Poland due to the closure of 29 coal mines and job restrictions in other mines. More than one half of this number refers to the Katowice conurbation.

\subsection{Re-industrialisation}

Since the early $1990 \mathrm{~s}$, the restructuring and closure of industries in the Katowice conurbation have been accompanied by the re-industrialisation of the region. Re-industrialisation is the effect of the expansion and modernisation of some existing industrial plants on the one hand, and on the other, of new industrial investments in brownfields and blackfields, as well as in greenfields. The core elements of re-industrialisation have been investments in the automotive industry, with the expanded and modernized plant in Tychy (Fiat Auto Poland) and the brand new plant in Gliwice (Opel production) becoming centres of the development in the sector. Investments in the automotive industry in the Czech Republic and Slovakia have also played an important role (e.g. Volkswagen, Hyundai, Toyota, Kia, Peugeot). Many plants have been created in the Katowice region to cater for the needs of the automotive plants in these three countries and, although they work for various concerns, it should be stressed that most of them cooperate with plants located in Poland (for example, Magneti Marelli).

From this point of view, the essence of the development of the automotive industry in the region of Katowice, but also in the Silesian Province more broadly, is relatively well captured in the concept of New Industrial Districts (NIDs) presented by Markusen (1996). To specify, from the structural point of view, it presents "the hub-andspoke" model highlighted by Markusen, although not in all industries. From a functional point of view, however, the "satellite platform" model is closer to real connections. Such a differentiation does not exclusively refer to the Katowice conurbation, but it may constitute a more general remark to the issue of development of some branches of industry (i.e. automotive) in Central and Eastern Europe (Ženka et al., 2015, p. 69).

The "hub-and-spoke" model emphasises the priority of the local system for the needs of a large manufacturing plant, as a network of smaller suppliers is formed. At the same time, the corporate and ownership dependence here it is not always an obstacle, at least in the case of new industry in the Katowice conurbation. It should be emphasised, however, that this model can only be applied to describe the automotive industry in the region. It is rarely representative of the newlyestablished plants of other industries not directly related to the automotive, such as the electro-technical, machine, mineral, chemical or meat industries. Their location is relatively casual and attractive forces were agglomeration economies and economic, legal and administrative profits resulting from the location in the Katowice Special Economic Zone (the KSEZ), or other privileged local economic zones. Most brand new large industrial plants were built in Gliwice and Tychy (greenfields type investments), Sosnowiec (brownfields), Katowice (brownfields), Dąbrowa Górnicza (brownfields), Siemianowice Śląskie (greenfields and brownfields). This quite specific location of new investments clearly reflects what is contained in the scientific metaphors of Markusen: "sticky places in slippery space" or even the "borrowed size of towns" proposed by Alonso. These issues are expanded in the following section.

The re-industrialisation of the region also consisted of a significant expansion and modernisation of certain industries traditional to the region. A brand new image has been given to the local large coal-fired power stations, in particular the "Eagisza" power station in Będzin and Chorzów, and "Jaworzno II" and "Jaworzno III" in Jaworzno. The coke plant "Przyjaźń", the largest in the region, has been modernized.

A significant part of the process of re-industrialisation is based on small and medium-sized companies of all sectors in all towns of the conurbation. The nature and investment policy of these companies vary: some of them function in the privileged KSEZ, some have built new plants outside the zone, and others use the buildings, sometimes modernized, of formerly existing companies. 


\section{Local development paths of industry in the Katowice conurbation}

\subsection{Introduction}

In comparison to large monocentric agglomerations, the conditions for industrial development in polycentric conurbations are relatively good. Here, services naturally limit the role of industry and push it outside the town. The process is facilitated by rent land rates, which are higher in the centre and much lower in the peripheries. In the case of large area investments, this significantly restricts development in the centre of the town, and not infrequently in the town itself. Generally, in such agglomerations industry is less competitive than services, particularly when its peripheral location runs the risk of limited transport accessibility.

Due to polycentricity, in urban conurbations the crosssection level of land rents is shaped like a wave. The value of land rent on the transverse axis increases near city centres and decreases away from them (Fujita, Thisse, 2002, p. 201-209). The differences between the crest of the wave and its base are not, however, as great as in the case of the centre of a monocentric agglomeration and its periphery. The inner-city niches of the location economies that appear in conurbations constitute an important element attracting new industries. Their advantage is also the fact that they are densely populated and have good transport facilities (the factor of job market accessibility).

Due to the dynamics of urbanisation and industrialisation, there are many brownfields and other investment areas available. With respect to re-industrialisation, the fact that they are owned by one or, less frequently, two or three persons is another advantage. Taking into account the often fragmented ownership of greenfields in the suburbs, this is a potential asset.

This seemingly unusual phenomenon derives from the fact that many investors expect a rapid start for their business activities. Hence, they are willing to bear greater financial expenditures on regeneration and decontamination of a brownfield belonging to one legal institution (entity $)^{4}$, rather than wrestle with the purchase of a dozen or dozens of smaller greenfield plots. Due to the fact that some small plot owners are not interested in selling them, and some other plots have an unresolved legal status, as a result, the investment process becomes extended in time, which frequently and often ultimately discourages potential investors. ${ }^{5}$

On the other hand, the re-industrialisation of such regions may be limited by the excessive degradation of post-industrial areas and by too heavy urbanisation (here: residential functions), which may hamper the development of industrial functions. As the example of some cities in the Katowice conurbation demonstrates, however, re-industrialisation can be successful, particularly in areas were the disadvantages of the conurbation were minimized by locating industries within its borders.

De-industrialisation and re-industrialisation in the Katowice region are uneven processes: i.e. many towns are still at the late post-industrial stage while others are at the post-industrial stage (Fig. 3).
To be precise, in 2010, there were only five typically industrial cities, where the number of employees in industry exceeded 55\% (Bieruń, Knurów, Lędziny, Łaziska Górne, Miasteczko Śląskie). In two cases - Dąbrowa Górnicza and Jaworzno - industry and services employ a relatively similar number of people (45-55\%). In most cities, however, the percentage of employees in industry decreased to below $40 \%$, often even below $30 \%$. For example, in the years 1989-2010, the employment share in industry in Będzin fell from 70\% to 25\%, in Mysłowice from 80\% to 34\%, and in Świętochłowice from 70\% to 33\% (CSO data, 2011).

Apart from this, as already mentioned, a key element in the process of economic transformation is its reindustrialisation, which is most preferably presented based on the models of the "borrowed size of towns" and "sticky places in slippery space". Both models indicate an unevenness of development of the region conditioned by the local inter-city competition. Determinants of competitive advantages are many, ranging from administrative and academic functions, good transport accessibility, traditions for development of certain industries in a particular city, with a final emphasis on the role of local actors and on the creativity of municipal government and local leaders. The result is the apparent economic success of some cities compared to the failures of others. The "oversized" cities in this respect certainly include Gliwice and Tychy, and among the smaller towns - Siewierz. All three of these centres also meet the criteria of sticky places in the region. The example of Gliwice is discussed later in this section. At this point, the growing role of this city, not only in the Katowice conurbation but also in southern Poland, will be highlighted. These differences are reflected quite well in Fig. 3. Bytom is placed on the opposite side: twenty years ago, it was one of the largest industrial centres in Poland, and today, due to strong de-industrialisation, it is the most problematic city in the country.

A characteristic feature of the spatial differentiation of new investments is the fact of their peripheral locations. In the centre of the region, a clearly visible slippery space developed. The situation is particularly unfavourable in the central-western part. While in the south-eastern part the term "slippery space" (towards new industrial investments) is mitigated by the functioning of traditional industries, in the central-western part it is associated with fairly advanced de-industrialisation.

In order to explain the essence of the changes in the industrial structure of the Katowice conurbation, the cases of three cities: Gliwice, Knurów and Bytom, which represent the most common types of industrial transformations in the region, are presented below.

\subsection{The case of a re-industrialised city - Gliwice}

Until 1990, the town of Gliwice was based on industries and services. The key sectors were bituminous coal mining (two large mines), the steel industry (two steelworks), and metal, electro-technical, and chemical industries. As a result of economic transformations, one mine and one of the steelworks have been closed down. The steelworks and metal plant have been thoroughly restructured. The plants from

\footnotetext{
${ }^{4}$ The most famous example in the Katowice conurbation is "EXPO-SILESIA" - Exhibition and Trade Centre in Sosnowiec, where its location, on a brownfield, required a lot of demolition and was ultimately more favourable than the initially contemplated prestigious location on the outskirts of Cracow (greenfields).

${ }^{5}$ In many cases, the costs of regeneration, and especially decontamination, are born by local governments and institutions connected with environmental protection (e.g. just closed (2016) WATT factory in Sosnowiec).
} 


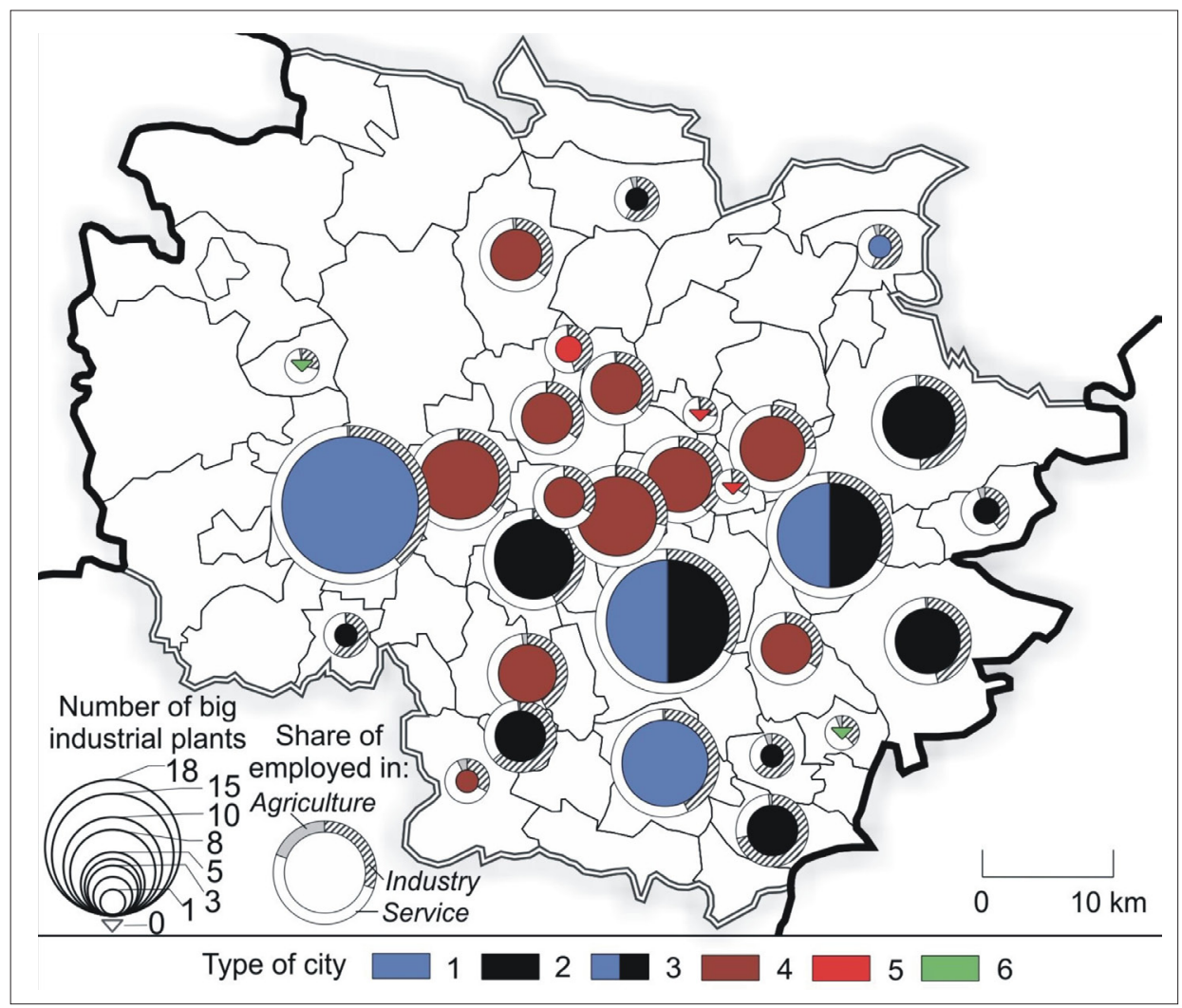

Fig. 3: Types of industrialisation dynamics in towns of the Katowice conurbation (Legend: 1 - towns with almost exclusively new or radically modernised industrial plants. Old industries have been replaced by new ones; 2 - towns whose economic structure is dominated by traditional industries. Lack of new industrial investments; the development of the city is based on traditional industries; 3 -towns in which new industrial plants are developed alongside the existing old industrial plants which have completed the process of restructuring. Old industries are replaced or balanced by new industrial investments; 4 -towns in which most traditional industries plants have been closed down, but in which new industries have not been developed; 5 -towns in which traditional industries plants have been completely closed down and new industries have not been developed; 6 -towns with no industrial function or with a limited industrial function in the past and at present)

Source: authors

other sectors built before 1990 have been almost completely restructured or closed down. The new stage of economic development of the town began with the establishment of the KSEZ investment areas and the flagship investment in Gliwice - an Opel automotive plant (currently General Motors Manufacturing Poland). The automotive plant and favourable local conditions, such as the availability of higher professional education (Silesian Polytechnic University) and a very good transportation network (a highway junction, an important railway hub, an inland port), stimulated the inflow of new investors from the industrial and service sectors. A key role in the industrial sector is held by automotive industry (including Deadong, General Motors, HP, Kirchoff, Nexteer, NGK Ceramics, Plastic Omnium Auto, Tenneco Automotive, and TRW Braking Systems).

Companies located in Gliwice are closely linked to General Motors Manufacturing Poland, as well as other automotive factories in the CEE. The essence of the "oversizing" of Gliwice as a centre of industry was not so much the creation of a special economic zone or a large number of cooperating plants, as the strengthening of a company that would be stimulating the economy and boost the influx of new companies in the automotive industry. Positive feedbacks were reported quickly as Opel accelerated the development of plants producing components. These, in turn, perpetuated the status of the Opel's Polish factory in the global structure of General Motors. Both the development of the Opel factory and the cooperating companies actuated the expansion of the special economic zone, also for other industries. Gliwice, in the early $2000 \mathrm{~s}$, became the most recognisable sticky place in the Katowice conurbation, struggling with restructuring and the liquidation of traditional industries.

Re-industrialisation of Gliwice at the turn of the twenty-first century meant that the city, like no other in the Katowice conurbation, is the antithesis of the postindustrialism concept in the analysed region. Even though in the period 1989-2010, the number of people employed in industry decreased from 64.5 thousand to 38.8 thousand, the share of the industry decreased only from $65 \%$ to $42 \%{ }^{6}$. This is a relatively small rate of decline in relation to many cities in the region, Poland and CEE. The growing importance of services based largely on logistics is closely connected with the local industry and endogenous services aiming at meeting the needs of residents. The fundamental importance in the economic development of Gliwice, however, was absolutely given to new industries. Taking into account the typology of the evolution of industrial regions proposed by Phelps and Ozawa, the city is difficult to define in the context of

${ }^{6}$ Taking into account logistics, which is closely related to industry, the rate fell to approximately $50 \%$. 
the suggested late-industrial or post-industrial stages. On a regional scale, Gliwice represents the type of city whose evolution is opposed to the one-way evolution visible in Phelps and Ozawa's model.

\subsection{The case of a post-industrial city - Bytom}

The situation in Bytom is completely different from that in Gliwice. Until the end of the twentieth century, Bytom was one of the largest mining and industrial centres in the region and was dominated by bituminous coal mining, the steel industries and other companies working for mining and heavy industries in the region. The "Bytom" clothing company was a well-known brand.

The depletion of deposits and the economic and structural problems of the Polish mining industry at the turn of the century led to the closure of most of the mines, and the closure and restructuring of steelworks. In 2015, only one large coal mine (about 1.5 thousand employees) and a small one ( 0.2 thousand employees) were functioning. The larger coal mine will be closed in the future.

At present, Bytom is the best example in Poland of a town affected by de-industrialisation. Except for the restructured steelworks, a power plant and the soon-to-be closed coal mine, there are no large and medium-sized industrial plants. The town has experienced the drastic results of urban shrinkage (rapid depopulation, the highest number of unemployed in the whole region, and the most serious social and spatial problems in the administrative territory of the town). Urban shrinkage and the strong inter-town competition in the Katowice conurbation resulted in a relatively weak development of exogenous, pro-development services. Services are predominantly endogenous. In KantorPietraga's (2014) system of depopulating and shrinking towns, Bytom is described as "a functionally useless town."

Bytom is a classic example of highly advanced postindustrialism. In contrast to Gliwice, no clear reindustrialism processes have taken place here. The employment in industry is in a steady decline. After the liquidation of mining, the share of industrial employment is going to fluctuate around 20-25\% (almost exclusively small and medium-sized companies). From the point of view of the metaphor "sticky places in slippery areas", Bytom clearly represents the latter type of geographical space. The term "slippery" in reference to Bytom was even strengthened by Gwosdz (2012), with the application of the term of "leaping" through the expected stages of postindustrialism, and, specifically in this case, mitigating the resulting problems by the potential new projects connected with services or production. Undoubtedly, the most serious mistake of the economic policy towards Bytom was the too late (2014-2015) inclusion of selected investment zones into the structure of the KSEZ - the most dynamic actor on the regional economic scene.

\subsection{The case of a (still) industrial city - Knurów}

The genesis and development of Knurów are linked to bituminous coal mining. The economic base of the town was formed by two mines: "Knurów" and "Szczygłowice," currently organisationally joined as KWK - "KnurówSzczygłowice." In this century, the obsolete coke plant was closed down. Local chemical industries have been thoroughly restructured. Knurów is one of the most interesting examples of a town in the Katowice region where, despite the closure and restructuring of two larger industrial plants (the coke plant and the industrial plants), traditional industries (coal mining) continue to stabilize economic development. In 2010, 59\% of all the employed in Knurów consisted of people employed in industry. Thus, this town is one of the places which make it difficult to use the term "postindustrial" to describe the Katowice region. In the taxonomy proposed by Phelps and Ozawa, the development of the town should be described as situated between the industrial and late-industrial stage.

This city is located in the peripheral zone of Gliwice and it represents a typical example of a slippery space. Even though Knurów is located on a major A1 highway, the strong competition of Gliwice deprives the place of the possibility of re-industrialisation on a broader scale. These restrictions are further aggravated by the negative impact of the local coal industry. Municipalities around Knurów are coping well with attracting new investors. The metaphor of slippery areas may in this case be complemented with "slippery on detour".

\section{Trans-industrialism as a response to post- industrialism dilemmas}

A key problem presented in this paper is the definitional dissonance regarding the question whether the term "postindustrial" can be used to describe a region in which there simultaneously appear processes of re-industrialisation (Gliwice) and of the stabilisation of traditional industries (Knurów). From the perspective of the activated mechanisms of de-industrialisation of the so-called traditional industries, the answer is certainly positive. The changes in this regard generally follow a one-way trajectory; after all, even if coal mining continues in Knurów, the coke plant based on coal has been closed down. Assuming that the end of the trajectory is determined by complete de-industrialisation (understood as the closure of former industrial plants), then the question emerges of "When the end will take place?". We do not know the answer to that. What we do know, however, is that the Katowice region does not fully follow the scenario described by Phelps and Ozawa (2003, p. 586), who set the end of the late-industrial stage at the end of the twentieth century.

Instead, what we observe is a spatial structure characterised by a marked lack of internal balance of development. According to Gwosdz (2012), who analysed the characteristic features of the economic base and employment in the towns of the Katowice conurbation, only six towns - Będzin, Chorzów, Gliwice, Katowice, and Sosnowiec - can be described as post-industrial. The problem is that even in this group, the role of industry and re-industrialisation is quite significant, as demonstrated by the example of Gliwice. Also, as other research shows (Gwosdz, Sobala-Gwosdz, 2012, p. 500), $45 \%$ of the employed in the towns of the conurbation work in the sectors of mining industry and industrial production.

The problems with definition become even more important when we attempt to determine precisely the process of industrialisation. Therefore, the question is whether reindustrialisation occurs when:

- new industrial plants appear in general, including plants based on advanced technologies;

- the economic potential of new industrial plants begins to dominate over the still existing (at the time of analysis) plants representing the so-called traditional industries; and

- the economic potential connected with new investments begins to dominate over the lost economic potential 
linked to the closed-down industrial plants representing the so-called old industries (i.e. Tkocz, 2001; Martin and Sunley, 2006; Trippl and Otto, 2009).

Finally, a reference should be made to the spatial redistribution of the re-industrialisation phenomenon. The metaphor of Markusen, "sticky places in slippery areas", that well reflects the reality of the region, significantly breaks apart the previously uniform and consistent mining and industrial region. Dualism in development is deepened with every decade, visibly transforming the hitherto industrial region consisting of dozens of medium-sized and large industrial centres into a network of cities with limited linkages in terms of industry (with the exception of the automotive industry).

As the argument to date suggests, the problems with defining post-industrialism in the Katowice conurbation are caused by our lack of knowledge (at this given moment) about the possibilities of future development of the industry in a given region. Is the development of the process of reindustrialisation at its highest point? Or is it only a stage in its development? A completely new perspective on the process of re-industrialisation has been proposed by Martinát et al. (2014), who use Karviná, a town in the Ostrava region, to argue that re-industrialisation may be based even on traditional industries (the mining industry in Karviná).

The problem of post-industrialism should also be approached from other two sides. The first one is the purely empirical perspective. In this case, a post-industrial region is one where there can be observed a decrease in the number of workers employed in industries and a decline in the proportion of workers employed in industries in relation to those employed in general or in services. This is an irrefutable argument for treating a region as post-industrial, particularly when both tendencies become more significant.

Firstly, a lot of companies classified as service companies work exclusive for industry and in industrial plants. While outsourcing concerns both production facilities and offices, it is included within the service sector in employment statistics. Before the early 1990 s, in postsocialist countries these groups of employees were the workers of given industrial plants. For example, in 2001, in the largest steelworks in the Katowice region, 'Huta Katowice' in Dąbrowa Górnicza, there were employed approximately 5.2 thousand workers, and over 7 thousand worked in subsidiary companies and businesses producing for the steelworks. Many of the companies were classified as services. At the same time, it should be pointed out that in 1996 in Huta Katowice there were 20.3 thousand employees and there was no division into the two groups of workers. Therefore, the actual decrease in the number of employees due to the restructuring of Huta Katowice shows that part of the workers changed the sector of the economy without changing the work place.

Second, another problem is the question of strongly developed endogenous services (the employed in the region provide services for the inhabitants of the region). These services are not city-forming factors, and therefore form a secondary sector in relation to exogenous services (the employed in the region provide services for those living outside the region) and industry. The quantity and quality of exogenous services are revealed by the low level of employment in exogenous services and industries, as well as by the overall demographic potential. The latter is a crucial issue in the Katowice conurbation (Krzysztofik et al., 2014). Examining closely the structure of employment in the towns of the Katowice conurbation, we note that the predominance of those employed in services is, to a large extent, an effect of the high proportion of workers employed in endogenous services. It is particularly visible in shrinking towns and in towns defined as post-industrial (Runge et al., 2014).

Taking into account the evolution of the economic base of the Katowice conurbation as discussed above, we cannot offer an adequate and uncontroversial definition of the region's present economic development. The definitional dissonance is a result of, among other factors, the following issues:

- the diverse stages of the process of de-industrialisation of the so-called old industries;

- the uneven character of the process of re-industrialisation; and

- the partly overestimated real role of services.

The "post-industrial region" is a very ambiguous term, especially as defined by Phelps and Ozawa (2003), who appropriated Hall's (1997) concept of post-industrial agglomeration. Kuciński (2008) and Gwosdz (2012) have recently questioned this definition; as Kuciński (2008, p. 165) writes: "The fact that the industrial function has disappeared or is disappearing in a given town does not have to mean that it is connected with a shift in economy from the industrial to the post-industrial stage." In turn, Gwosdz (2012) has proposed to describe the Katowice conurbation as a lateindustrial region. Indeed, this claim may be supported by the great number of towns in the Katowice conurbation whose economy is based on the so-called traditional industries. At the same time, however, this description does not fully reflect the economic status of those towns where traditional industries have been closed down or have been significantly restructured and have been replaced by new industries, as has been the case in, for example, Gliwice or Tychy.

It is also difficult to describe the Katowice conurbation as a (late-)industrial region, if only because of the significant role of services. Undoubtedly, as has been shown, some towns in the regions are (late-)industrial. Thus, in order to contribute to the discussion on the nature of the functional transformations of such regions as the Katowice conurbation, we propose to describe the region as transindustrial (Fig. 4). Currently, the term is employed in two ways. In a wider sense, it is related to the character of the social change in the world caused by the role of industry as one of the quantifiers of overall social development in the history of civilisation (Kassiola, 1990). More narrowly, it has been used to explain specific organisational connections in the media market (Meehan, 2005)

In this situation, we would like to draw attention to the process-oriented value of the term in the functional approach - in direct relation to such terms as industrialism, post-industrialism, or re-industrialism. The meaning of this term may also be manifested in the fact that:

- it represents an alternative to the terms late-industrial or post-industrial, especially when the definition of these two stages is questionable;

- it emphasizes the continuity and sustainability of industrial development in the region - a sustainability, which, contrary to stereotypical assumptions, is characterized by the variability of key industries in the region;

- it underlines the fact that neighbouring towns can simultaneously function at very different stages of functional evolution in relation to the development of industry; 
- it presents re-industrialisation as an alternative to the deindustrializing path of functional transformations; and

- it finds a place in the general trajectory of transformations for such objects as the fossil-fuel power station "Łagisza" in Będzin which, on the one hand, belongs to the traditional industries in the region and, on the other, after modernisation and extension, is one of the most technologically advanced facilities of this type in Europe.

Above all, "trans-industrialism" departs from the sharp division into stages proposed by Phelps and Ozawa which, in complex settlement systems like polycentric agglomerations or conurbations, can lead to some inconsistencies. Importantly, it suggests that we should see the transformations as a whole in which Phelps and Ozawa's taxonomy, as well as the phenomena of de-industrialisation and re-industrialisation, are included (Fig. 4).

What is a trans-industrial region? It is a defined region (administrative, economic, urban) which includes towns and settlements at various stages of industrialisation, starting from proto-industrialism and ending with postindustrialism, and in which there appear theoretically opposing trends in economic transformations, such as deindustrialisation and re-industrialisation.

\section{Discussion}

The above definition of trans-industrialism begs the question of whether the term is not tantamount to industrialism, where the latter is understood as the development of industry in general. It is definitely not. Transindustrialism is a much more narrow term. If industrialism points to the overall processes connected to the development of industry in general, trans-industrialism emphasises a specific moment of the development - the here and now. The development includes also the quite diverse evolution of industrial functions in individual towns in the region.

Of course, the term "here and now" is not clear and needs to be clarified. The first issue to be resolved is the issue of the region. Theoretically, the area having the same boundaries at the time of research as in the defined past should be subject to analysis. A barrier to such a depiction of delimitation is the fact that some cities, once they have lost industrial functions and become centres of service industries, "alienate" themselves with respect to the industrial region, with which they were identified even 15 or 20 years before. This process is not dynamic, but noticeable, especially in areas where the industrial region is experiencing an enhanced crisis, and the examined city with services is developing based on the new functions. Changes of administrative boundaries are also problematic, as well as the social and economic delimitations introduced due to various needs. In the Katowice conurbation, administrative changes took place in 1999. Since the 1990 s, at least a dozen delimitation projects for the region have been developed.

The time aspect is even more difficult to define. Unless we are able to determine the upper dividing line - the present at the time of research, it is more difficult to determine the lower line of division. In Poland and the CEE countries, the

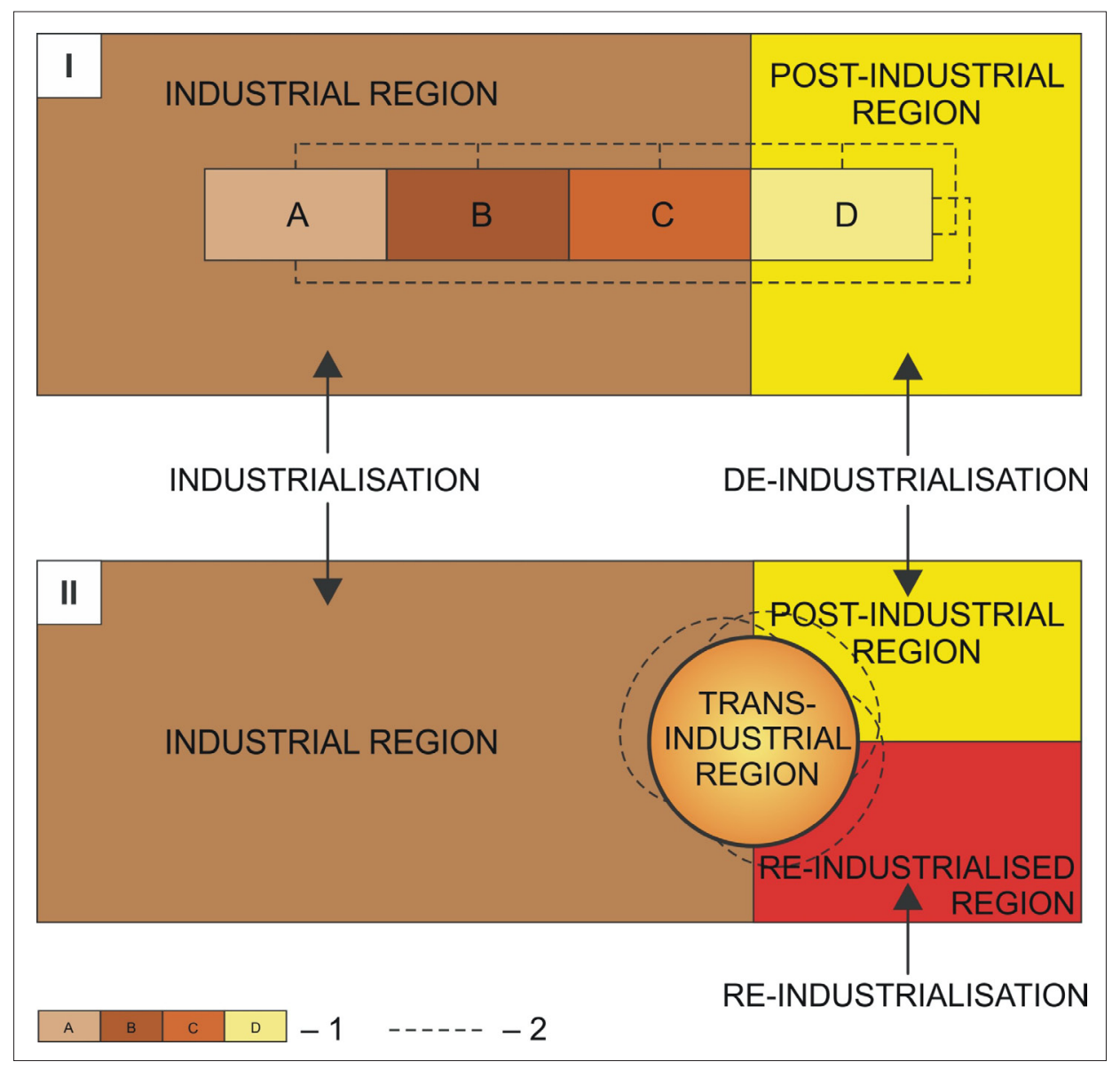

Fig. 4: Model concepts and the location of the trans-industrial region (Legend: I - Phelps and Ozawa's model; II - the authors' model; I-Phelps and Ozawa's model (A-pre-industrial stage; B-industrial stage; $C$-late-industrial stage; $D$ - post-industrial stage); II - range of changes in future - possibilities.

Source: authors 
period 1989-1990 might be helpful since it refers to the time of the collapse of the socialist system. A more "fluid" nature of the lower dividing line will be in countries where there was a continuity of the capitalist economy. Referring back to the upper dividing line - the present, however, it should be considered to what point of time we are able to extend the period of study. While for the Katowice conurbation, the period 1990-2015 does not raise any doubts, would it be the same for the period 1990-2030?

The term "trans-industrial" has been proposed as a point of departure for a discussion about the spatial and temporal heterogeneity of economic processes and phenomena, and about the formation of town functions. It is proposed as an answer to the restrictions imposed by the currently used terms and definitions, in particular by the term "postindustrial region".

This seemingly fairly simple idea is followed by a number of methodological challenges. They mainly concern the ways to assess the role of industry in the regional economy. The methodology in this regard is diverse and significantly complex, starting from simple participation rates of employees in the industry relative to the total number of employees, and ending at fairly complicated procedures, integrating factors of employment, investment, GDP or the number of large enterprises. All of these attributes may be considered both in terms of traditional industries and also new industrial plants. Although there are a number of comparison tools, an undoubted challenge is their clarification. One should assume, however, that getting unanimity on this issue is not going to be easy - even more so due to the fact that a thorough analysis of the issue will also be required for the services sector, the functioning of which is not always possible to be compared simply with the industrial sector.

Despite these undoubtedly objective limitations to the application of the trans-industrialism concept, the authors are convinced that undertaking further studies in this matter, both in terms of methodology, case studies and further theoretical explanations, is worthwhile.

\section{Conclusions}

The functional transformations in Central European urban regions whose economy has been until recently based mostly on mining and traditional industries, are very diverse. They depend on many factors, the most important of which are the relocation of industry in Europe; GDP; the spatial form of an urban region (conurbation, polycentric agglomeration, monocentric agglomeration), or regional factors, such as labour market, transportation network and economic policy. In this article, however, we have attempted to explain these determinants and their influence on the functional identity of a region.

With respect to the Katowice conurbation - the largest urban region of this type in Central-Eastern Europe the authors have demonstrated the difficulties involved in defining it in terms of literal post-industrialism. The difficulties are caused by, on the one hand, the interaction between the actual de-industrialisation of the region and the marked signs of its re-industrialisation, and, on the other, by the limited range, at least with respect to demographic potential, of the replacement of industries by exogenous services, particularly by those which could create a functional alternative in the future. Additionally, these are accompanied by the process of de-industrialisation and the shrinkage of some of towns in the conurbation.
The problems with offering an unequivocal definition of the changing functions of the Katowice conurbation have led us to propose the term "trans-industrial" to describe the region. This allows us to uphold a dynamic approach to the changes and to evade answering the question whether the region should be defined in line with the Phelps and Ozawa taxonomy as post-industrial or late-industrial. The proposal to define the region as trans-industrial does not mean that we should stop evaluating and analysing industrialism and post-industrialism in the specific towns of the conurbation. On the basis of the trajectory of the transformations of functions in "model" towns, it is advisable to anticipate changes in functionally complex towns. The importance of the challenge follows the original assumption that urban regions, such as conurbations, are, in fact, strongly integrated urban systems. The problems of one town "spread" to the neighbouring towns. In the Katowice conurbation, it is clearly visible in the directions and intensity of commuting to work. Despite some differences, the Katowice region may be a point of reference for other East Central European urban regions described as post-industrial, such as the Ostrava and Rybnik regions.

\section{References:}

BIRCH, K., MACKINNON, D., CUMBERS, A. (2010): Old industrial regions in Europe: a comparative assessment of economic performance. Regional Studies, 44(1): 35-53.

BOROWIK, I. M. (2014): Knowledge Exchange Mechanisms and Innovation Policy in Post-Industrial Regions: Approaches of the Basque Country and the West Midlands. Journal of Knowledge Economy, 5(1): 37-69.

BURGER, M. J., MEIJERS, E. J., HOOGERBRUGGE, M. M., TRESSERRA, J. M, (2015): Borrowed Size, Agglomeration Shadows and Cultural Amenities in North-West Europe. European Planning Studies, 23(6): 1090-1109.

COENEN, L., MOODYSSON, J., MARTIN, H. (2014): Path Renewal in Old Industrial Regions: Possibilities and Limitations for Regional Innovation Policy. Regional Studies, 1-16. (early view): DOI: dx.doi.org/10.1080/0034 3404.2014.979321.

COOKE, P. [ed.] (1995): The Rise Of The Rustbelt: Revitalizing Older Industrial Regions. London, UCL Press Limited.

CORNETT, A. P. (2013): Conceptualisation of Clusters as a Tool in Local and Regional Development. In: Brown K., et al. [eds.]: Resources and Competitive Advantage in Clusters (pp. 30-45). München-Mering, Rainer Hampp Verlag.

VAN DIJK, H. (2002): The Decline of Industry the Ruhr Area in Germany. Paper presented to the Urban History Conference Edinburgh.

DOMAŃSKI, B. (2002): The economic restructuring of Upper Silesian region. In: Stober, G. [ed.]: Polen, Deutschland und die Osterweiterung der EU aus geographischen Perspektiven (pp. 91-103). Hannover, Verlag Hahnsche Buchhandlung,

DOMAŃSKI, B. (2003): Economic trajectory, path dependency and strategic intervention in an old industrial region: the case of Upper Silesia. In: Domański, R. [ed.]: Recent advances in urban and regional studies. Studia Regionalia KPZK PAN, 11: 133-153. 
DUBENETSKII, Y. N. (2014): Reindustrialization: Conditions, Goals, and Stages. Studies on Russian Economic Development, 25(4): 329-334.

ECKART, K. [ed.] (2003): Social, economic and cultural aspects in the dynamic changing process of old industrial regions. Ruhr District (Germany), Upper Silesia (Poland), Ostrava Region (Czech Republic). Münster, LIT.

FRANZ, P. (2010): Political Institutionalisation and Economic Specialisation in Polycentric Metropolitan Regions: The Case of the East German 'Saxony Triangle'. Urban Studies, 47(12): 2665-2682.

FUJITA, M., THISSE, J.-F. (2002): Economics of Agglomeration. Cities, Industrial Location and Regional Growth. Cambridge, Cambridge University Press.

GWOSDZ, K. (2012): Baza ekonomiczna i specjalizacja funkcjonalna miast konurbacji katowickiej po dwóch dekadach transformacji. Acta Geographica Silesiana, 11: 15-29.

GWOSDZ, K. (2014): Pomiędzy starą a nową ścieżką rozwojową. Mechanizmy ewolucji struktury gospodarczej i przestrzennej region tradycyjnego przemysłu na przykładzie konurbacji katowickiej po 1989 roku. Kraków, IGiGP Uniwersytet Jagielloński.

GWOSDZ, K., SOBALA-GWOSDZ, A. (2012): Struktura funkcjonalna i powiązania miast konurbacji katowickiej po dwóch dekadach restrukturyzacji. Przegląd Geograficzny, 84(4): 483-507.

HALL, P. (1997): Modelling the post-industrial city. Futures, 29(4-5): 311-322.

HAMILTON, E. F. I. (1984): Industrial Restructuring: an International Problem. Geoforum, 15(3): 28-39.

HASSINK, R., SHIN, D. H. (2005): The restructuring of old industrial areas in Europe and Asia. Environment and Planning A, 37(4): 571-580.

HRUŠKA-TVRDÝ, L. (2010): Proměny trhu práce v Ostravě. In: Tvrdý-Hruška, L. [ed.]: Industriálni město v postindustriálni společnosti. Ostrava: VŠB-TU.

HUDEC, O., URBANČIKOVÁ, N. (2008): Spatial Disparities based on Human and Social Capital. In: Jenks, M. D., Kozak P. [eds.]: World Cities and Urban Form. Fragmented, polycentric, sustainable? (pp. 113-128). New York, London, Takkanon, Routledge.

KANTOR-PIETRAGA， I. (2014): Systematyka procesu depopulacji miast na obszarze Polski od XIX do XXI wieku. Katowice, Wydawnictwo Uniwersytetu Śląskiego.

KASSIOLA, J. J. (1990): The Death of Industrial Civilization. The Limits to Economic Growth and the Repoliticization of Advanced Industrial Society. Albany, State University of New York Press.

KLASIK, A. [ed.] (2008): Aktywność przedsiębiorcza i konkurencyjność ekonomiczna miast w procesie restrukturyzacji aglomeracji miejskich, Katowice, Wydawnictwo Akademii Ekonomicznej w Katowicach.

KLASIK, A., HEFFNER, K. (2001): Polish Regional Policy and the Problems of Upper Silesia Ten Years into Transformation. In: Klasik, A., Heffner, K. [eds.]: Restructuring Heavy Industrial Regions. Some Experience from Scotland and Upper Silesia (pp. 11-34). Katowice, Wydawnictwo Akademii Ekonomicznej im. Karola Adamieckiego.
KLOOSTERMAN, R. C., LAMBREGTS, B. (2001): Clustering of economic activities in polycentric urban areas: the case of Randstad. Urban Studies, 38(4): 717-732.

KNAPP, W. (1998): The Rhine-Ruhr area in transformation: Towards a European metropolitan region? European Planning Studies, 6(4): 379-393.

KRUGMAN, P. (1997): Development, Geography and Economic Theory. Cambridge, London, The MIT Press.

KRZYSZTOFIK, R. (2014): Geneza aglomeracji miast na obszarze Polski. Katowice, Wydawnictwo Uniwersytetu Śląskiego.

KRZYSZTOFIK, R., KANTOR-PIETRAGA, I., SPÓRNA, T. (2013): A Dynamic approach to the typology of functional derelict areas (Sosnowiec, Poland). Moravian Geographical Reports, 21(2): 20-35.

KRZYSZTOFIK, R., RUNGE, A., RUNGE, J., KANTORPIETRAGA, I. (2014): Miasta konurbacji katowickiej. In: Stryjakiewicz, T. [ed.]: Kurczenie się miast w Europie Środkowo-Wschodniej (pp. 89-101). Poznań, Bogucki Wydawnictwo Naukowe.

KUCIŃSKI, K. (2008): Miasto w procesie dezindustrializacji. In: Morawski, W. Zawistowski, A. [eds.]: Stare Okręgi Przemysłowe. Dylematy industrializacji i dezindustrializacji (pp. 161-179). Warszawa, Oficyna Wydawnicza SGH w Warszawie.

LEBOUTTE, R. (2009): A space of European deindustrialisation in the late of twentieth century: Nord/ Pas-de Calais, Wallonia and the Ruhrgebiet. European Review of History: Revue europeene d'histoire (Special Issue: Transnational Spaces in History), 16(5): 755-770.

LEVER, W. F. (1991): Deindustrialisation and the Reality of the Post-industrial City. Urban Studies, 28(6): 983-999.

LUX, G. (2009): Divergent patterns of adaptation among Central European Old Industrial Regions. European Spatial and Research Policy, 16(1): 145-157.

MARKUSEN, A. (1996): Sticky places in slippery spaces: a typology of industrial districts. Economic Geography, 72(1): 293-313.

MARTIN, R., SUNLEY, P. (2006): Path dependence and regional economic evolution. Journal of Economic Geography, 6(4): 395-437.

MARTINÁT, S., NAVRÁTIL, J., DVOŘÁK, P., KLUSÁČEK, P., KULLA, M., KUNC, J., HAVLÍČEK, M. (2014): The expansion of coal mining in the depression areas - a way to development. Human Geographies - Journal of Studies and Research in Human Geography, 8(1): 5-15.

MEEHAN, E. R. (2005): Transindustrialism and synergy: structural supports for decreasing diversity in commercial culture. International Journal of Media \& Cultural Politics, 1(1): 123-126.

MEIJERS, E. J. (2008): Measuring polycentricity and its promises. European planning Studies, 16(9): 1313-1323.

MIKOŁAJEC, J. (2008): Spatial Restructuring of the Katowice Conurbation. In: Nowak, M., Nowosielski, M. [eds.]: Declining Cities/Developing Cities: Polish and German Perspectives (pp. 101-112). Poznań, Wydawnictwo Instytutu Zachodniego.

MÜLLER, B., FINKA, M., LINTZ, G. [eds.] (2004): Rise and Decline of Industry in Central and Eastern Europe. Berlin, Springer. 
MUSIL, J. (2010): Modely vývoje měst a procesy deindustrializace. In: Tvrdý-Hruška, L. [ed.]: Industriální město $\mathrm{v}$ postindustriálni společnosti (pp. 21-32). Ostrava, Vysoká škola báňská-Technická univerzita.

NEFFKE, F., HENNING, M., BOSCHMA, R. (2011): How do region diversify over time? Industry relatedness and the development of new growth paths in regions. Economic Geography, 87(3): 237-265.

PARR, J. B. (2004): The Polycentric Urban Region: A Closer Inspection. Regional Studies, 38(3): 231-240.

PHELPS, N.A., OZAWA, T. (2003): Contrasts in agglomeration: proto-industrial, industrial and post-industrial form compared. Progress in Human Geography, 27(5): 583-604.

PICKERNELL， D., ROWE, P. A., CHRISTIE, M. J., BROOKSBANK, D. (2007): Developing a framework for network and cluster identification for use in economic development policy-making. Entrepreneurship \& Regional Development, 19(4): 339-358.

POPJAKOVÁ, D., TKOCZ, M., VANČURA, M. (2014): New Industrial Spaces in Old Industrial Centres: Selected Examples of Sosnowiec (Poland) and České Budějovice (Czech Republic). In: Zioło, Z., Rachwał, T. [eds.]: Contemporary issues of Polish industrial geography (pp. 212-229). Kraków, Prace Komisji Przemysłu PTG.

RILEY, R., TKOCZ, M. (1998): Coal Mining in Upper Silesia under Communism and Capitalism. European Urban and Regional Studies, 5(3): 217-235.

RUNGE, J., KANTOR-PIETRAGA, I., KRZYSZTOFIK, R., RUNGE, A. (2014): Model urbanizacji złożonych układów osadniczych w świetle procesu kurczenia się miast w Polsce - próba analizy krytycznej. In: Stryjakiewicz, T. [ed.]: Kurczenie się miast w Europie Środkowo-Wschodniej (pp. 115-125). Poznań, Bogucki Wydawnictwo Naukowe.

RUMPEL, P., SLACH, O. (2012): Governance of Shrinkage of the City of Ostrava. Praha, European Science and Art Publishing.

SCHUYSKY, V.P. (2013): Foreign economic relations of Russia Reindustrialization of Russia: Opportunities of Technology Import. Russian Foreign Economic Journal, 1(1): 101-108.

SCOTT, A. (1982): Locational patterns and dynamics of industrial activity in the modern metropolis. Urban Studies, 19(2): 111-142.
SCOTT, A., STORPER, M. (1987): High technology industry and regional development: a theoretical critique and reconstruction. International Social Science Journal, 112: 215-232.

STEINER, M. (2003): Modernizing Traditional Industries in Declining Regions - Concepts of Transformation in Old and New Market Economies. In: Steiner, M. [ed.]: From Old Industries to New Regions. Policies for Structural Transformations in Accession Countries (pp. 9-24). Graz, Leykam Buchverlagsgesselschaft.

STRANGELMANN, T. (2002): Networks, Place and Identities in Post-industrial Mining Communities. International Journal of Urban and Regional Research, 25(2): 253-267.

SUCHÁČEK, J. (2005): Regional Decline and Restructuring in Ostrava Agglomeration and Katowice Conurbation. ERSA conference papers ersa05p200, European Regional Science Association [cit. 03.03.2015]. Available at: https://www.researchgate.net/publication /23731503_ Regional_Decline_and_Restructuring_in_Ostrava_ Agglomeration_and_Katowice_Conurbation

SUCHÁČEK, J. (2010): Na cestě k nové identitě: Ostrava, Katovice a Košice po roce 1989. Ostrava, Vysoká škola báňská, Technická univerzita.

SWAIN, A. [ed.] (2007): Re-Constructing the Post-Soviet Industrial Region: The Donbas in Transition. Abingdon, Routledge.

TKOCZ, M. (2001): Restrukturyzacja przemysłu regionu tradycyjnego. Katowice, Wydawnictwo Uniwersytetu Śląskiego.

TKOCZ, M. (2006): Efekty restrukturyzacji górnictwa węglowego w Polsce. Prace Komisji Geografii Przemysłu PTG, 9: 28-38.

TRIPPL, M., OTTO, A. (2009): How to turn the fate of old industrial areas: a comparison of cluster-based renewal processes in Styria and the Saarland. Environment and Planning A, 41(5): 1217-1233.

WESTKÄMPER, E. (2014): Towards the Re-Industrialization of Europe. A Concept for Manufacturing 2030. Berlin, Heidelberg, Springer Verlag.

WIRTH, P., ČERNIČ MALI, B., FISCHER, W. [eds.] (2012) Post-mining Regions in Central Europe. Problems, Potentials, Possibilities. München, oekon Verlag.

ŽENKA, J., NOVOTNÝ, S., SLACH, O., KVĚTOŇ, V. (2015): Industrial specialization and economic performance: A case of Czech microregions. Norsk Geografisk TidsskriftNorwegian Journal of Geography, 69(2): 67-79.

Please cite this article as:

KRZYSZTOFIK, R., TKOCZ, M., SPÓRNA, T., KANTOR-PIETRAGA, I. (2016): Some dilemmas of post-industrialism in a region of traditional industry: The case of the Katowice conurbation, Poland. Moravian Geographical Reports, 24(1): 42-54. Doi: 10.1515/mgr-2016-0004. 